Terbit online pada laman : http://teknosi.fti.unand.ac.id/

Jurnal Nasional Teknologi dan Sistem Informasi

ISSN (Print) 2460-3465 | ISSN (Online) 2476-8812 |

Artikel Penelitian

\title{
Analisis Sentimen Twitter untuk Menilai Opini Terhadap Perusahaan Publik Menggunakan Algoritma Deep Neural Network
}

\author{
Erwin Yudi Hidayat ${ }^{a,}{ }^{*}$, Raindy Wicaksana Hardiansyah ${ }^{a}$, Affandy $^{a}$ \\ ${ }^{a}$ Fakultas Ilmu Komputer, Universitas Dian Nuswantoro, Semarang, 50131, Indonesia
}

\section{INFORMASI ARTIKEL}

Sejarah Artikel:

Diterima Redaksi: 13 Juli 2021

Revisi Akhir: 06 September 2021

Diterbitkan Online: 10 September 2021

\section{KATA KUNCI}

Analisis Sentimen,

Twitter,

Klasifikasi,

Perusahaan Publik,

Deep Neural Network

\section{KORESPONDENSI}

E-mail: erwin@dsn.dinus.ac.id*

\section{A B $\mathbf{S}$ T $\mathbf{R}$ A $\mathbf{C}$ T}

\begin{abstract}
Dalam menaikkan kinerja serta mengevaluasi kualitas, perusahaan publik membutuhkan feedback dari masyarakat / konsumen yang bisa didapat melalui media sosial. Sebagai pengguna media sosial Twitter terbesar ketiga di dunia, tweet yang beredar di Indonesia memiliki potensi meningkatkan reputasi dan citra perusahaan. Dengan memanfaatkan algoritma Deep Neural Network (DNN), neural network yang tersusun dari layer yang jumlahnya lebih dari satu, didapati hasil analisa sentimen pada Twitter berbahasa Indonesia menjadi lebih baik dibanding dengan metode lainnya. Penelitian ini menganalisa sentimen melalui tweet dari masyarakat Indonesia terhadap sejumlah perusahaan publik dengan menggunakan DNN. Data Tweet sebanyak 5504 record didapat dengan melakukan crawling melalui Application Programming Interface (API) Twitter yang selanjutnya dilakukan preprocessing (cleansing, case folding, formalisasi, stemming, dan tokenisasi). Proses labeling dilakukan untuk 3902 record dengan memanfaatkan aplikasi Sentiment Strength Detection. Tahap pelatihan model dilakukan menggunakan algoritma DNN dengan variasi jumlah hidden layer, susunan node, dan nilai learning rate. Eksperimen dengan proporsi data training dan testing sebesar 90:10 memberikan hasil performa terbaik. Model tersusun dengan 3 hidden layer dengan susunan node tiap layer pada model tersebut yaitu 128, 256, 128 node dan menggunakan learning rate sebesar 0.005 , model mampu menghasilkan nilai akurasi mencapai $88.72 \%$.
\end{abstract}

\section{PENDAHULUAN}

Perusahaan Publik adalah Perseroan Terbatas seperti yang dimaksud dalam Pasal 1 angka 1 Ketentuan Umum Undangundang Nomor 40 Tahun 2007 tentang Perseroan Terbatas. Sahamnya telah dimiliki sekurang-kurangnya oleh 300 (tiga ratus) pemegang saham dan memiliki modal disetor sekurangkurangnya Rp 3.000.000.000 (tiga miliar rupiah) atau suatu jumlah pemegang saham dan modal disetor yang ditetapkan dengan Peraturan Pemerintah [1]. Dalam menaikkan kinerja serta mengevaluasi kualitas dalam suatu perusahaan maka dibutuhkan feedback berupa opini yang dapat didapatkan dari website perusahaan tersebut ataupun melalui sosial media [2].
Twitter adalah microblogging platform yang sangat populer. Layanan jejaring sosial ini memungkinkan pengguna untuk membagikan 240 karakter melalui suatu tweet [3]. Pada pertengahan tahun 2015, jumlah pengguna Twitter di Indonesia mencapai lima puluh juta pengguna. Hal ini menjadikan Indonesia sebagai negara dengan pengguna aktif Twitter terbanyak ketiga di dunia [4]. Dengan pengelolaan yang tepat, Twitter dapat dimanfaatkan sebagai ladang keuntungan bagi perusahaan atau seseorang yang memiliki kepentingankepentingan tertentu untuk meningkatkan reputasi dan citranya. Media tersebut banyak digunakan oleh masyarakat untuk sekedar meluapkan emosinya maupun membagikan suatu informasi [3]. Banyak perusahaan publik yang memiliki akun Twitter untuk memberikan informasi dan berinteraksi dengan konsumennya. Interaksi tersebut dilakukan melalui unggahan Twitter yang disebut tweet. Interaksi antar masyarakat dan perusahaan 
tentunya dapat berupa pendapat, saran, ataupun kritik terhadap suatu hal [5]. Tweet tentang perusahaan publik sangat beragam. masyarakat dapat menulis tweet yang berupa komentar positif ataupun negatif tentang suatu perusahaan. Perusahaan publik dapat memanfaatkan hal tersebut untuk mengetahui bagaimana citra perusahaan di masyarakat. Namun terjadi kesulitan dalam pemanfaatan itu pada saat melakukan klasifikasi kalimat, mengingat banyaknya unggahan tweet maka dibutuhkan waktu dan usaha yang besar jika proses klasifikasi dilakukan secara manual [4]. Oleh karena itu perlu dilakukan analisis sentimen.

Analisis sentimen merupakan bagian dari text mining yang memelajari komputasi opini orang-orang, emosi, dan sentimen dan bertujuan untuk mengklasifikasikan sentimen pada suatu kalimat yang berupa opini. Analisis sentimen dapat menentukan apakah kalimat tersebut merupakan kalimat positif atau negatif berdasarkan polaritasnya [6]. Analisa sentimen dapat digunakan untuk mengetahui sentimen pengguna Twitter terhadap perusahaan publik. Tweet dapat dikategorikan berdasarkan sentimen kalimatnya dan dapat memberikan informasi terhadap tanggapan masyarakat yang memengaruhi citra perusahaan publik. Penelitian mengenai analisis sentimen dilakukan oleh [7] yang membahas klasifikasi sentimen wisatawan Candi Borobudur pada situs Tripadvisor menggunakan Support Vector Machine (SVM) dan K-Nearest Neighbour. Kemudian penelitian lain juga dilakukan oleh [8] membahas mengenai analisis sentimen terhadap ulasan hotel menggunakan Boosting Weighted Extreme Learning Machine. Lalu [9] melakukan penelitian tentang analisis sentimen berbasis aspek pada ulasan pelanggan restoran Bakso President malang dengan metode Nä̈ve Bayes Classifier. Dalam penelitian tersebut data set dilakukan preprocessing terlebih dahulu sehingga data yang akan diklasifikasi menjadi bersih dan siap untuk diolah menggunakan algoritma tertentu.

Artificial Neural Network (ANN) adalah sistem komputasi yang diadopsi dari jaringan syaraf otak manusia yang memiliki kemampuan untuk belajar dan berkembang. Pada ANN, Jaringan syaraf ini diinterpretasikan menjadi graf yang memiliki bobot dan arah [10]. Salah satu penerapan dari neural network adalah Deep Neural Network atau DNN. Deep Neural Network adalah neural network yang tersusun dari layer yang jumlahnya lebih dari satu [11]. Penelitian yang menggunakan DNN dilakukan oleh [12] untuk menganalisa sentimen pada Twitter berbahasa Indonesia mengenai institusi pemerintahan dan tokoh pemerintahan. Penelitian tersebut membandingkan metode Deep Learning Neural Network dengan SVM dan Naïve Bayes. Hasil penelitian yang didapat menunjukkan bahwa performa metode DNN lebih baik dari metode lainnya.

Penelitian ini bertujuan menerapkan metode DNN untuk melakukan analisis sentimen pada tweet berbahasa Indonesia mengenai perusahaan publik di Indonesia. Akurasi dari DNN juga menjadi bahasan yang diangkat. Dari tujuan tersebut, penelitian dapat mendukung perusahaan dalam melakukan analisis sentimen opini publik terhadap reputasi atau citra perusahaan publik yang ada di masyarakat. Sehingga, perusahaan dapat mendapatkan umpan balik untuk menentukan langkah strategis dan kebijakan yang akan ditempuh selanjutnya.

\section{METODE}

\subsection{Sumber Data}

Penelitian ini menggunakan sumber data yang berupa tweet yang diambil secara lansung dari sosial media Twitter. Data diambil dengan memanfaatkan Application Programming Interface (API) yang telah disediakan oleh Twitter.

Data yang diambil pada penelitian ini menggunakan beberapa kata kunci seperti 'myxlcare', 'telkomsel', 'indihome', 'satpam bca', 'indomie', 'indofood'. Kata kunci tersebut merupakan kata kunci pada tweet yang berkaitan dengan perusahaan publik di Indonesia, seperti Unilever, Indofood, BCA, BRI, Maybank, Telkom Indonesia, dan XL Axiata. Data tersebut kemudian disimpan pada file yang berformat Comma Separated Values (CSV).

\subsection{Metode Pengumpulan Data}

Studi literatur dilakukan dengan cara mengumpulkan data dan informasi melalui buku, literatur ilmiah, jurnal, dan media online yang dapat dijadikan sebagai pendukung untuk menunjang referensi dan landasan teori yang sesuai dengan penelitian ini.

Observasi dilakukan dengan cara mengamati dan mengambil data secara langsung pada sosial media Twitter. Pengambilan dilakukan dengan memanfaatkan Twitter API yang telah disediakan oleh Twitter.

\subsection{Tahap Penelitian}

Data diambil dengan memanfaatkan API yang telah disediakan oleh Twitter. Untuk menggunakan Twitter API, sebelumnya harus melakukan pendaftaran akun pengembang. Akun tersebut dapat digunakan untuk mendapatkan API key dan access token yang berperan sebagai kunci pengaksesan Twitter API. Kemudian digunakan library Tweepy untuk mempermudah pengaksesan Twitter API pada Python. Teknik crawling yang digunakan adalah teknik dengan menggunakan kata kunci nama perusahaan atau produk dari suatu perusahaan.

Data set yang sudah terambil kemudian dilakukan preprocessing yang bertujuan untuk mengurangi noise sehingga data yang dihasilkan menjadi terstruktur dan siap untuk diolah menggunakan metode DNN. Tahapan yang ada pada preprocessing ini antara lain case folding yaitu proses dimana seluruh karakter pada data set diubah menjadi huruf kecil. Kemudian cleansing yaitu proses untuk menghapus URL, mention, hashtag, retweet, symbol, dan angka. Lalu dilakukan pengubahan kata pada data set menjadi kata baku. Setelah itu dilakukan stemming untuk mengubah kata pada data set menjadi kata dasar. Data tersebut kemudian diterapkan tokenisasi untuk memisahkan kata pada setiap teks menjadi kata yang independen

Dataset yang sudah diproses dibagi menjadi dua yaitu data training dan data testing. Data training digunakan sebagai data untuk melatih model sedangkan data testing digunakan sebagai data untuk melakukan pengujian model.

Data set kemudian diklasifikasikan dengan metode DNN dan dilakukan pengujian untuk mengukur performa model. 


\subsection{Text Processing}

Text Preprocessing merupakan proses pengolahan teks yang bertujuan untuk mengurangi noise pada data set serta mengubah data set menjadi bentuk yang lebih terstuktur. Tahapan text preprocessing yang diterapkan pada penelitian ini adalah cleansing, case folding, formalisasi, stemming, dan tokenisasi. Berikut merupakan tahapan text preprocessing yang ditunjukkan pada Gambar 1.

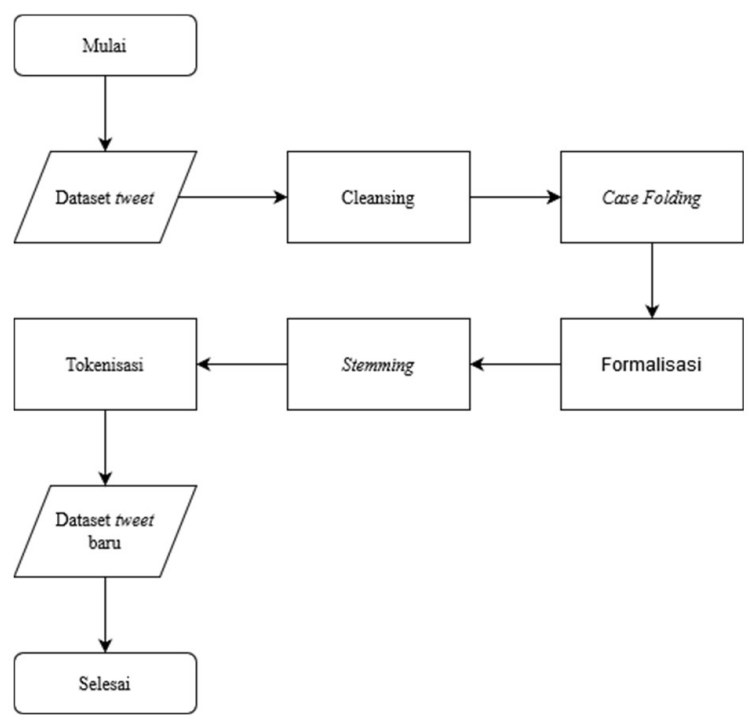

Gambar 1. Flowchart Text Preprocessing

\subsubsection{Cleansing}

Proses cleansing merupakan proses dimana teks dilakukan penyederhanaan terhadap karakter atau komponen yang tidak berpengaruh untuk proses klasifikasi. Proses ini menghapus komponen data seperti duplikasi, mention, atribut yang diawali dengan retweet, dan atribut yang diawali dengan hashtag, URL, simbol, dan angka. Gambar 2 merupakan flowchart dari cleansing, dan contoh cleansing ditunjukkan oleh Tabel 1.

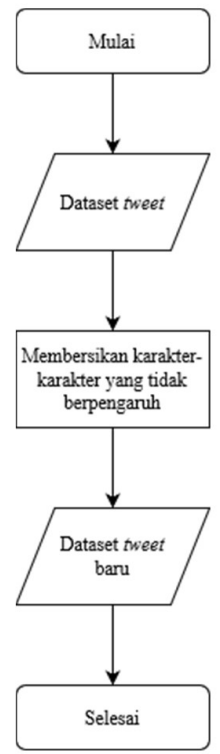

Gambar 2. Flowchart Cleansing
Tabel 1. Contoh Cleansing

\begin{tabular}{|c|c|}
\hline Masukan & Keluaran \\
\hline $\begin{array}{l}\text { Emang ya pegawai paling ramah } \\
\text { cuma satpam bank bca, bank } \\
\text { sulselbar sama pramuniaga } \\
\text { uniqlo. yang lain jutek bgt } \\
\text { padahal kan ya dia digaji dari } \\
\text { hasil belanjaan gue }\end{array}$ & $\begin{array}{l}\text { Emang ya pegawai paling ramah } \\
\text { cuma satpam bank bca bank } \\
\text { sulselbar sama pramuniaga } \\
\text { uniqlo yang lain jutek bgt } \\
\text { padahal kan ya dia digaji dari } \\
\text { hasil belanjaan gue }\end{array}$ \\
\hline $\begin{array}{l}\text { (a) IchaVarma satpam bank bca } \\
\text { emg terbaik sih pd sopan dan } \\
\text { ramah bgt }\end{array}$ & $\begin{array}{l}\text { satpam bank bca emg terbaik sih } \\
\text { pd sopan dan ramah bgt }\end{array}$ \\
\hline \begin{tabular}{l}
\multicolumn{4}{l}{ Sekarang indihome terlalu sering } \\
gangguan gk asik banget \\
indihome skrng gk pernah \\
berbenah kalah ama tetangganya.
\end{tabular} & $\begin{array}{l}\text { Sekarang indihome terlalu sering } \\
\text { gangguan gk asik banget } \\
\text { indihome skrng gk pernah } \\
\text { berbenah kalah ama tetangganya }\end{array}$ \\
\hline $\begin{array}{l}\text { Astagfirullah malam malam } \\
\text { pengen bikin indomie, kalau aku } \\
\text { bikin sangat berdosa sekali pada } \\
\text { tubuh ini :)) }\end{array}$ & $\begin{array}{l}\text { Astagfirullah malam malam } \\
\text { pengen bikin indomie kalau aku } \\
\text { bikin sangat berdosa sekali pada } \\
\text { tubuh ini }\end{array}$ \\
\hline $\begin{array}{l}\text { @safirahtasa Makanan aja sih } \\
\text { gue banyak maunya parah. } \\
\text { Ditambah psbb makin banyak } \\
\text { maunya dan jauh. Ter random } \\
\text { waktu itu gue mimpi makan es } \\
\text { krim walls strawbery cheesecake } \\
\text { di pabriknya jd sekeliling gue es } \\
\text { krim semua. Pas bangun pengen } \\
\text { bgt tapi jam } 2 \text { pagi dinihari :) }\end{array}$ & $\begin{array}{l}\text { Makanan aja sih gue banyak } \\
\text { maunya parah Ditambah psbb } \\
\text { makin banyak maunya dan jauh } \\
\text { Ter random waktu itu gue mimpi } \\
\text { makan es krim walls strawbery } \\
\text { cheesecake di pabriknya jd } \\
\text { sekeliling gue es krim semua Pas } \\
\text { bangun pengen bgt tapi jam pagi } \\
\text { dinihari }\end{array}$ \\
\hline
\end{tabular}

\subsubsection{Case Folding}

Case folding merupakan proses untuk memeriksa semua karakter pada data set dan mengubahnya menjadi huruf kecil. Gambar 3 merupakan flowchart dari case folding.

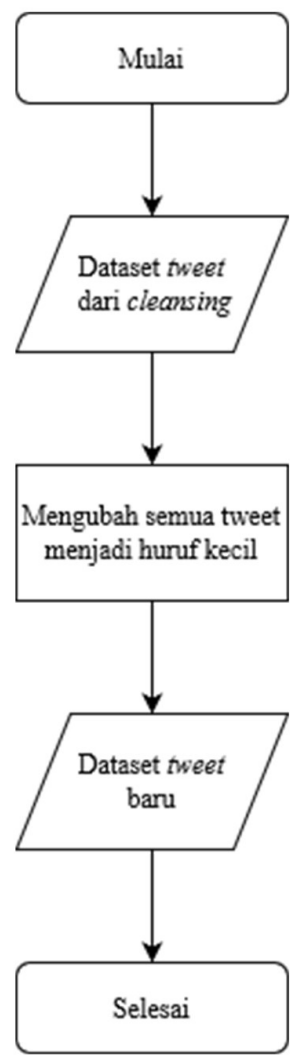

Gambar 3. Flowchart Case Folding 
Tabel 2. Contoh Case Folding

\begin{tabular}{|c|c|}
\hline Masukan & Keluaran \\
\hline $\begin{array}{l}\text { Emang ya pegawai paling ramah } \\
\text { cuma satpam bank bca bank } \\
\text { sulselbar sama pramuniaga } \\
\text { uniqlo yang lain jutek bgt } \\
\text { padahal kan ya dia digaji dari } \\
\text { hasil belanjaan gue }\end{array}$ & $\begin{array}{l}\text { emang ya pegawai paling ramah } \\
\text { cuma satpam bank bca bank } \\
\text { sulselbar sama pramuniaga } \\
\text { uniqlo yang lain jutek bgt } \\
\text { padahal kan ya dia digaji dari } \\
\text { hasil belanjaan gue }\end{array}$ \\
\hline $\begin{array}{l}\text { satpam bank bca emg terbaik sih } \\
\text { pd sopan dan ramah bgt }\end{array}$ & $\begin{array}{l}\text { satpam bank bca emg terbaik sih } \\
\text { pd sopan dan ramah bgt }\end{array}$ \\
\hline $\begin{array}{l}\text { Sekarang indihome terlalu sering } \\
\text { gangguan gk asik banget } \\
\text { indihome skrng gk pernah } \\
\text { berbenah kalah ama tetangganya }\end{array}$ & $\begin{array}{l}\text { sekarang indihome terlalu sering } \\
\text { gangguan gk asik banget } \\
\text { indihome skrng gk pernah } \\
\text { berbenah kalah ama tetangganya }\end{array}$ \\
\hline $\begin{array}{l}\text { Astagfirullah malam malam } \\
\text { pengen bikin indomie kalau aku } \\
\text { bikin sangat berdosa sekali pada } \\
\text { tubuh ini }\end{array}$ & $\begin{array}{l}\text { astagfirullah malam malam } \\
\text { pengen bikin indomie kalau aku } \\
\text { bikin sangat berdosa sekali pada } \\
\text { tubuh ini }\end{array}$ \\
\hline $\begin{array}{l}\text { Makanan aja sih gue banyak } \\
\text { maunya parah Ditambah psbb } \\
\text { makin banyak maunya dan jauh } \\
\text { Ter random waktu itu gue mimpi } \\
\text { makan es krim walls strawbery } \\
\text { cheesecake di pabriknya jd } \\
\text { sekeliling gue es krim semua Pas } \\
\text { bangun pengen bgt tapi jam pagi } \\
\text { dinihari }\end{array}$ & $\begin{array}{l}\text { makanan aja sih gue banyak } \\
\text { maunya parah ditambah psbb } \\
\text { makin banyak maunya dan jauh } \\
\text { ter random waktu itu gue mimpi } \\
\text { makan es krim walls strawbery } \\
\text { cheesecake di pabriknya jd } \\
\text { sekeliling gue es krim semua pas } \\
\text { bangun pengen bgt tapi jam pagi } \\
\text { dinihari }\end{array}$ \\
\hline
\end{tabular}

\subsubsection{Formalisasi}

Formalisasi merupakan proses pengubahan setiap kata yang memiliki ejaan yang tidak tepat menjadi kata yang sesuai dengan kaidah Bahasa Indonesia. Gambar 4 merupakan flowchart dari formalisasi. Tabel 3 merupakan contoh dari formalisasi.

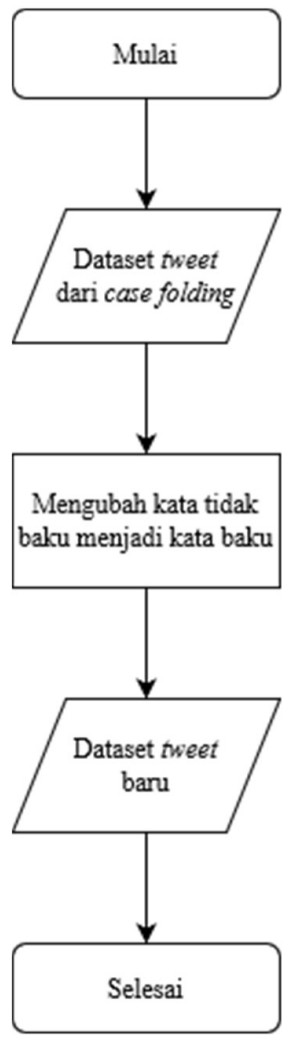

Gambar 4. Flowchart Formalisasi
Tabel 3. Contoh Formalisasi

\begin{tabular}{|c|c|}
\hline Masukan & Keluaran \\
\hline $\begin{array}{l}\text { emang ya pegawai paling ramah } \\
\text { cuma satpam bank bca bank } \\
\text { sulselbar sama pramuniaga } \\
\text { uniqlo yang lain jutek bgt } \\
\text { padahal kan ya dia digaji dari } \\
\text { hasil belanjaan gue }\end{array}$ & $\begin{array}{l}\text { memang iya pegawai paling } \\
\text { ramah cuma satuan pengamanan } \\
\text { bank bca bank sulselbar sama } \\
\text { pramuniaga uniqlo yang lain } \\
\text { galak banget padahal kan iya dia } \\
\text { digaji dari hasil belanjaan saya }\end{array}$ \\
\hline $\begin{array}{l}\text { satpam bank bca emg terbaik sih } \\
\text { pd sopan dan ramah bgt }\end{array}$ & $\begin{array}{l}\text { satpam bank bca memang terbaik } \\
\text { sih pada sopan dan ramah banget }\end{array}$ \\
\hline $\begin{array}{l}\text { sekarang indihome terlalu sering } \\
\text { gangguan gk asik banget } \\
\text { indihome skrng gk pernah } \\
\text { berbenah kalah ama tetangganya }\end{array}$ & \begin{tabular}{l}
\multicolumn{3}{c}{ sekarang indihome terlalu sering } \\
gangguan tidak asik banget \\
indihome sekarang tidak pernah \\
berbenah kalah sama \\
tetangganya
\end{tabular} \\
\hline $\begin{array}{l}\text { astagfirullah malam malam } \\
\text { pengen bikin indomie kalau aku } \\
\text { bikin sangat berdosa sekali pada } \\
\text { tubuh ini }\end{array}$ & $\begin{array}{l}\text { astagfirullah malam malam ingin } \\
\text { bikin indomie kalau aku bikin } \\
\text { sangat berdosa sekali pada tubuh } \\
\text { ini }\end{array}$ \\
\hline $\begin{array}{l}\text { makanan aja sih gue banyak } \\
\text { maunya parah ditambah psbb } \\
\text { makin banyak maunya dan jauh } \\
\text { ter random waktu itu gue mimpi } \\
\text { makan es krim walls strawbery } \\
\text { cheesecake di pabriknya jd } \\
\text { sekeliling gue es krim semua pas } \\
\text { bangun pengen bgt tapi jam pagi } \\
\text { dinihari }\end{array}$ & $\begin{array}{l}\text { makanan saja sih saya banyak } \\
\text { maunya parah ditambah psbb } \\
\text { makin banyak maunya dan jauh } \\
\text { ter random waktu itu saya mimpi } \\
\text { makan es kirim walls strawbery } \\
\text { cheesecake di pabriknya jadi } \\
\text { sekeliling saya es kirim semua } \\
\text { pas bangun ingin banget tapi jam } \\
\text { pagi dinihari }\end{array}$ \\
\hline
\end{tabular}

\subsubsection{Stemming}

Stemming merupakan proses untuk mengubah kata yang memiliki imbuhan menjadi kata akar atau kata dasarnya. Proses stemming pada penelitian ini dilakukan dengan menggunakan library Sastrawi. Gambar 5 merepresentasikan flowchart bagaimana stemming dikerjakan.

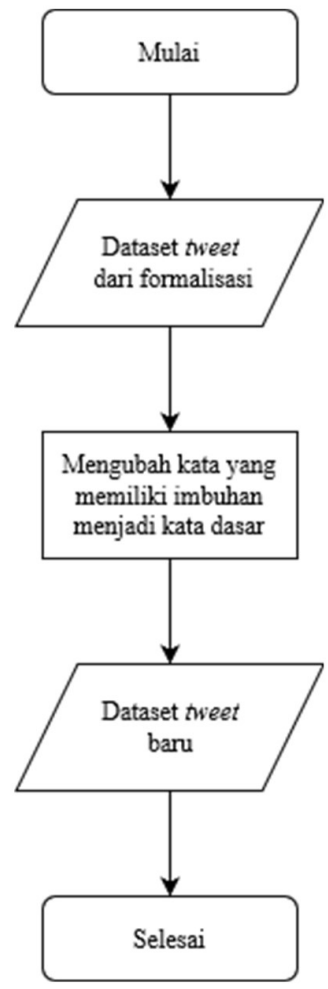

Gambar 5. Flowchart Stemming 
Adaupun Tabel 4 menggambarkan contoh dari stemming.

Tabel 4. Contoh Stemming

\begin{tabular}{ll}
\hline Masukan & Keluaran \\
\hline memang iya pegawai paling & memang iya pegawai paling \\
ramah cuma satuan pengamanan & ramah cuma satu aman bank bca \\
bank bca bank sulselbar sama & bank sulselbar sama pramuniaga \\
pramuniaga uniqlo yang lain & uniqlo yang lain galak banget \\
galak banget padahal kan iya dia & padahal kan iya dia gaji dari hasil \\
digaji dari hasil belanjaan saya & belanja saya \\
\hline satuan pengamanan bank bca & satpam bank bca memang baik \\
memang terbaik sih pada sopan & sih pada sopan dan ramah banget \\
dan ramah banget & \\
\hline sekarang indihome terlalu sering & sekarang indihome terlalu sering \\
gangguan tidak asik banget & ganggu tidak asik banget \\
indihome sekarang tidak pernah & indihome sekarang tidak pernah \\
berbenah kalah sama tetangganya & benah kalah sama tetangga \\
\hline astagfirullah malam malam ingin & astagfirullah malam malam ingin \\
bikin indomie kalau aku bikin & bikin indomie kalau aku bikin \\
sangat berdosa sekali pada tubuh & sangat dosa sekali pada tubuh ini \\
ini & \\
\hline makanan saja sih saya banyak & makan saja sih saya banyak mau \\
maunya parah ditambah psbb & parah tambah psbb makin banyak \\
makin banyak maunya dan jauh & mau dan jauh ter random waktu \\
ter random waktu itu saya mimpi & itu saya mimpi makan es kirim \\
makan es kirim walls strawbery & walls strawbery cheesecake di \\
cheesecake di pabriknya jadi & pabrik jadi keliling saya es kirim \\
sekeliling saya es kirim semua & semua pas bangun ingin banget \\
pas bangun ingin banget tapi jam & tapi jam pagi dinihari \\
pagi dinihari & \\
\hline
\end{tabular}

\subsubsection{Tokenisasi}

Tokenisasi adalah proses untuk memotong setiap kata pada data set menjadi kata yang independen. Gambar 6 merupakan flowchart dari tokenisasi, dengan contoh tokenisasi ditunjukkan pada Tabel 5 .

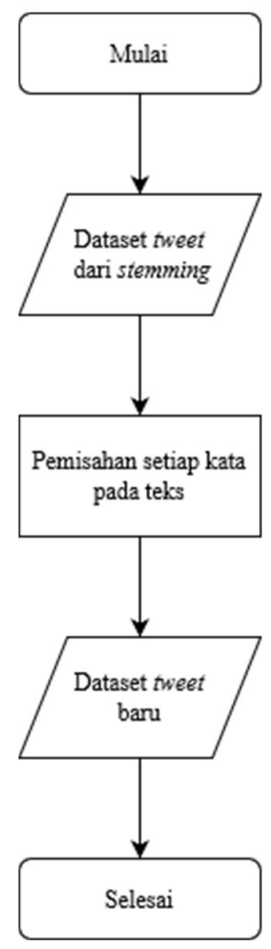

Gambar 6. Flowchart Tokenisasi
Tabel 5. Contoh Tokenisasi

\begin{tabular}{|c|c|}
\hline Masukan & Keluaran \\
\hline $\begin{array}{l}\text { memang iya pegawai paling } \\
\text { ramah cuma satu aman bank bca } \\
\text { bank sulselbar sama pramuniaga } \\
\text { uniqlo yang lain galak banget } \\
\text { padahal kan iya dia gaji dari hasil } \\
\text { belanja saya }\end{array}$ & $\begin{array}{l}\text { \{'memang' 'iya' 'pegawai' 'paling' } \\
\text { 'ramah' 'cuma' 'satu' 'aman' 'bank' } \\
\text { 'bca' 'bank' 'sulselbar' 'sama' } \\
\text { 'pramuniaga' 'uniqlo' 'yang' 'lain' } \\
\text { 'galak' 'banget' 'padahal' 'kan' 'iya' } \\
\text { 'dia' 'gaji' 'dari' 'hasil' 'belanja' } \\
\text { 'saya'\} }\end{array}$ \\
\hline $\begin{array}{l}\text { satu aman bank bca memang baik } \\
\text { sih pada sopan dan ramah banget }\end{array}$ & $\begin{array}{l}\text { \{'satpam' 'bank' 'bca' 'memang' } \\
\text { 'baik' 'sih' 'pada' 'sopan' 'dan' } \\
\text { 'ramah' 'banget'\} }\end{array}$ \\
\hline $\begin{array}{l}\text { sekarang indihome terlalu sering } \\
\text { ganggu tidak asik banget } \\
\text { indihome sekarang tidak pernah } \\
\text { benah kalah sama tetangga }\end{array}$ & $\begin{array}{l}\text { \{'sekarang' 'indihome' 'terlalu' } \\
\text { 'sering' 'ganggu' 'tidak' 'asik' } \\
\text { 'banget' 'indihome' 'sekarang' } \\
\text { 'tidak' 'pernah' 'benah' 'kalah' } \\
\text { 'sama' 'tetangga'\} }\end{array}$ \\
\hline $\begin{array}{l}\text { astagfirullah malam malam ingin } \\
\text { bikin indomie kalau aku bikin } \\
\text { sangat dosa sekali pada tubuh ini }\end{array}$ & $\begin{array}{l}\text { \{'astagfirullah' 'malam' } \\
\text { 'malam' 'ingin' 'bikin' } \\
\text { 'indomie' 'kalau' 'aku' 'bikin' } \\
\text { 'sangat' 'dosa' 'sekali' 'pada' } \\
\text { 'tubuh' 'ini'\} }\end{array}$ \\
\hline $\begin{array}{l}\text { makan saja sih saya banyak mau } \\
\text { parah tambah psbb makin banyak } \\
\text { mau dan jauh ter random waktu } \\
\text { itu saya mimpi makan es kirim } \\
\text { walls strawbery cheesecake di } \\
\text { pabrik jadi keliling saya es kirim } \\
\text { semua pas bangun ingin banget } \\
\text { tapi jam pagi dinihari }\end{array}$ & $\begin{array}{l}\text { \{'makan' 'saja' 'sih' 'saya' } \\
\text { 'banyak' 'mau' 'parah' 'tambah' } \\
\text { 'psbb' 'makin' 'banyak' 'mau' } \\
\text { 'dan' 'jauh' 'ter' 'random, } \\
\text { 'waktu' 'itu' 'saya' 'mimpi' } \\
\text { 'makan' 'es' 'kirim, 'walls' } \\
\text { 'strawbery, 'cheesecake' 'di' } \\
\text { 'pabrik' 'jadi' 'keliling, 'saya' } \\
\text { 'es' 'kirim' 'semua' 'pas' } \\
\text { 'bangun' 'ingin' 'banget' 'tapi' } \\
\text { 'jam' 'pagi' 'dinihari'\} }\end{array}$ \\
\hline
\end{tabular}

\subsection{Labeling}

Proses labeling dilakukan menggunakan aplikasi Sentiment Strength Detection dari hasil penelitian yang dilakukan oleh [13]. Aplikasi tersebut merupakan aplikasi labeling berbasis kamus yang meliputi kamus sentiword, questionword, negatingword, emoticon, dan boosterword.

Tabel 6. Sampel tweet setelah dilakukan labeling

\begin{tabular}{|c|c|c|}
\hline No. & Tweet & Label \\
\hline 1 & $\begin{array}{l}\text { Satpam BCA emang terbaik sih, padahal cuma } \\
\text { nganter temen tapi diperlakukan kayak putri raja } \\
\text { uhhh manjah wkwk }\end{array}$ & Positif \\
\hline 2 & $\begin{array}{l}\text { Beberapa hari lalu update @myXL @myXLCare } \\
\text { tapi belum sempet buka karena pikir 'ah paling } \\
\text { update minor doang' dan pagi ini terkaget-kaget } \\
\text { karena ternyata 'major' update dan aplikasinya } \\
\text { bagus banget, jauh lebih smooth dibanding myXL } \\
\text { versi sebelumnya. @XLAxiata_Tbk } \\
\text { https://t.co/FkatRYp6r0 }\end{array}$ & Positif \\
\hline 3 & $\begin{array}{l}\text { Pantesan pulsa XL aing habis ga jelas trs. Taunya } \\
\text { tiba-tiba terdaftar kaya ginian yg ga pernah aing } \\
\text { ikutan. Termasuk penipuan konsumen ga sih? } \\
\text { @myXLCare@myXL@TMCPoldaMetro } \\
\text { https://t.co/lfRbNJTOxt } \\
\text { https:/tt.co/co5Pp8XKeL;myxlcare }\end{array}$ & Negatif \\
\hline 4 & $\begin{array}{l}\text { @ guiijjsee@myXLCare Tolong dong, daerah } \\
\text { ponorogo juga. Dibuat wa bisa tapi untuk social } \\
\text { media yang lain MasyaAllah lemot nya. }\end{array}$ & Negatif \\
\hline 5 & $\begin{array}{l}\text { @sptwnangga Menurut lo recommended yang } \\
\text { mana? Sambal Tabur Boncabe atau Jawara cabai } \\
\text { tabur? }\end{array}$ & Netral \\
\hline 6 & $\begin{array}{l}\text { @ IndiHome malam, mau nanya kalo daerah bekasi } \\
\text { di daerah caman sudah tercover? terima kasih }\end{array}$ & Netral \\
\hline
\end{tabular}


Untuk menguji ketepatan aplikasi tersebut maka diambil masingmasing 20 data positif, 20 data negatif, dan 20 data netral dari data set. Data tersebut sebelumnya telah diberi label secara manual dan kemudian diuji dengan menggunakan aplikasi Sentiment Strength Detection. Hasil dari pengujian didapatkan akurasi dari aplikasi labeling tersebut adalah 96.67\%. Tabel 6 sampel dari tweet yang dilakukan proses labeling.

\subsection{Artificial Neural Network}

Artificial Neural Network adalah sistem komputasi yang diadopsi dari jaringan syaraf otak manusia yang memiliki kemampuan untuk belajar dan berkembang. Pada ANN, jaringan syaraf ini diinterpretasikan menjadi graf yang memiliki bobot dan arah [10].

Salah satu penerapan dari neural network adalah DNN. Deep Neural Network adalah neural network yang tersusun dari layer yang jumlahnya lebih dari satu. Pada setiap layer tersebut memiliki neuron yang jumlahnya bervariasi pada setiap layer. Kemudian setiap layer melakukan perhitungan jumlah bobot $\mathrm{w}$ dikali dengan input $\mathrm{x}$ yang ditambah dengan bias. Hasil perhitungan ini kemudian dihitung lagi dengan menggunakan fungsi aktivasi yang merupakan keluaran dari layer tersebut. Persamaan 1 merupakan perhitungan pada setiap layer [11].

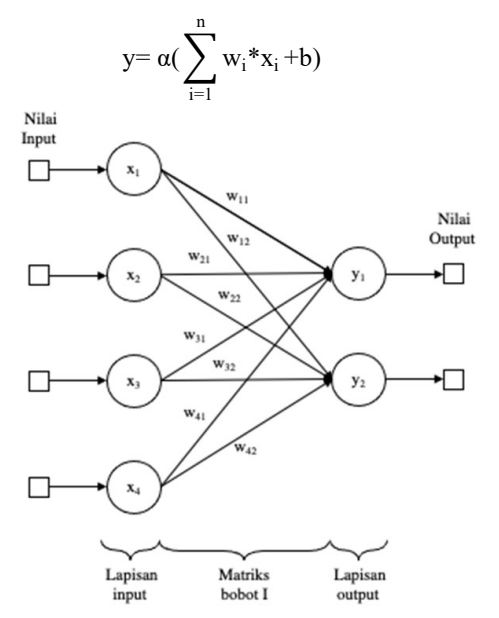

Gambar 7. Ilustrasi ANN

Fungsi aktivasi yang paling umum digunakan pada neural network meliputi hyperbolic tangent (tanh), sigmoid, dan rectified linear (ReLU). Berikut merupakan persamaan dari masing-masing fungsi aktivasi tersebut.

$$
\begin{gathered}
\tanh (x)=\frac{e^{x}-e^{-x}}{e^{x}+e^{-x}} \\
\operatorname{sigmoid}(x)=\frac{1}{1+e^{-x}} \\
\operatorname{ReLU}(x)=\max (0, x)
\end{gathered}
$$

Pada layer terakhir fungsi aktivasi yang dapat digunakan sebagai keluaran neuron adalah softmax. Fungsi softmax mengubah vektor n-dimensi yang berisi nilai riil menjadi vektor n-dimensi yang nilainya dalam rentang 0 sampai 1 . Berikut merupakan persamaan dari fungsi softmax [14].

$$
\operatorname{softmax}(\mathrm{x})_{\mathrm{j}}=\frac{\mathrm{e}^{\mathrm{x}}}{\sum_{\mathrm{k}=1}^{\mathrm{K}} \mathrm{e}^{\mathrm{x}}}, \text { for } \mathrm{j}=1, \ldots, \mathrm{K}
$$

\subsection{Metode yang Diusulkan}

Metode yang digunakan dalam penelitian ini menerapkan metode DNN. Klasifikasi dilakukan dengan dua tahap yaitu klasifikasi menggunakan training set yang bertujuan untuk melatih model dan klasifikasi menggunakan test set yang bertujuan untuk menguji model yang telah dilatih.

Tabel 7 merupakan vocabulary yang berisi seluruh kata yang ada pada data set yang kemudian diberi indeks. Pada indeks 0 terdapat token $<\mathrm{OOV}>$ yang bertujuan untuk mengisi kata yang kosong agar bentuk input sequence yang akan diklasifikasikan dengan model DNN berjumlah tetap atau sama.

Tabel 7. Contoh vocabulary

\begin{tabular}{ll}
\hline Indeks & Token \\
\hline 0 & $<$ OOV $>$ \\
\hline 1 & Produk \\
\hline 2 & Ini \\
\hline 3 & Sangat \\
\hline 4 & Bagus \\
\hline 5 & Jelek \\
\hline 0 & $<$ OOV $>$ \\
\hline
\end{tabular}

Pada Tabel 8 jumlah elemen sequence yang digunakan adalah sebanyak 6 elemen.

Tabel 8. Contoh Representasi Data

\begin{tabular}{lll}
\hline Tweet & Tweet Sequence & Kelas \\
\hline Produk ini sangat bagus & {$[1,2,3,4,0,0]$} & Positif \\
\hline Produk ini jelek & {$[1,2,5,0,0,0]$} & Negatif \\
\hline
\end{tabular}

Untuk mengklasifikasikan teks, model DNN memanfaatkan word embedding yang mengubah setiap kata dalam vocabulary menjadi vektor yang berisi angka. Tujuannya adalah untuk mengenali fitur pada setiap kata. Tabel 9 merupakan contoh word embedding dengan menggunakan dimensi embedding yang berjumlah $n$ dimensi.

Tabel 9. Contoh Word Embedding

\begin{tabular}{ll}
\hline Indeks Kata & Nilai Vektor \\
\hline 0 & {$\left[\mathrm{e}_{01}, \mathrm{e}_{02}, \mathrm{e}_{03}, \ldots, \mathrm{e}_{0 \mathrm{n}}\right]$} \\
\hline 1 & {$\left[\mathrm{e}_{11}, \mathrm{e}_{12}, \mathrm{e}_{13}, \ldots, \mathrm{e}_{1 \mathrm{n}}\right]$} \\
\hline 2 & {$\left[\mathrm{e}_{21}, \mathrm{e}_{22}, \mathrm{e}_{23}, \ldots, \mathrm{e}_{2 n}\right]$} \\
\hline 3 & {$\left[\mathrm{e}_{31}, \mathrm{e}_{32}, \mathrm{e}_{33}, \ldots, \mathrm{e}_{3 \mathrm{n}}\right]$} \\
\hline 4 & {$\left[\mathrm{e}_{41}, \mathrm{e}_{42}, \mathrm{e}_{43}, \ldots, \mathrm{e}_{4 \mathrm{n}}\right]$} \\
\hline 5 & {$\left[\mathrm{e}_{51}, \mathrm{e}_{52}, \mathrm{e}_{53}, \ldots, \mathrm{e}_{5 \mathrm{n}}\right]$} \\
\hline
\end{tabular}

Tabel 9 memuat nilai vektor untuk masing-masing kata. Masingmasing indeks kata pada teks sequence di Tabel 8 kemudian dilakukan pencarian atau pencocokan dengan vektor word embedding. Vektor word embedding yang sesuai dengan teks sequence dirata-rata. Nilai rata-rata pada setiap vektor tersebut kemudian digunakan sebagai input neuron pada neural network untuk dilakukan klasifikasi.

Klasifikasi pada penelitian ini menggunakan algortima DNN dengan pre-trained word embedding FastText yang memiliki dimensi embedding sejumlah 300 dimensi. 


\subsection{Eksperimen dan Pengujian Model}

Eksperimen model dilakukan dengan kombinasi jumlah layer dan jumlah neuron yang berbeda-beda. Pengujian model dilakukan dengan menghitung akurasi pada training set dan testing set. Akurasi merupakan perhitungan total klasifikasi sentimen yang benar terhadap seluruh data yang ditunjukkan pada Persamaan 6 . Tabel 10 merupakan contoh data beserta klasifikasinya.

$$
\text { Akurasi }=\frac{\text { Jumlah klasifikasi benar }}{\text { Jumlah dokumen uji }} \times 100 \%
$$

Tabel 10. Contoh Data dan Kelas Prediksinya

\begin{tabular}{lll}
\hline Data ke- & Actual Class & Predicted Class \\
\hline 1 & Positif & Netral \\
\hline 2 & Positif & Positif \\
\hline 3 & Positif & Positif \\
\hline 4 & Negatif & Negatif \\
\hline 5 & Negatif & Negatif \\
\hline 6 & Negatif & Negatif \\
\hline 7 & Netral & Positif \\
\hline 8 & Netral & Negatif \\
\hline 9 & Netral & Negatif \\
\hline 10 & Netral & Netral \\
\hline
\end{tabular}

Pada Tabel 10 diperoleh 6 data dengan klasifikasi yang benar dan 4 data klasifikasi yang salah. Hasil tersebut dihitung akurasinya dengan Persamaan 6:

$$
\text { Akurasi }=\frac{6}{10} \times 100 \%=60 \%
$$

Dari perhitungan tersebut, nilai akurasi untuk contoh data pada Tabel 10 sebesar $60 \%$.

\section{HASIL}

\subsection{Pengumpulan Data}

Pengambilan data dilakukan dengan menggunakan Twitter API. Untuk dapat menggunakan API tersebut maka dibutuhkan akun Twitter developer dengan melakukan registrasi ke URL https://developer.Twitter.com/en/apply-for-access dan mengisi formulir pendaftaran dan ketentuan yang ditetapkan oleh pihak Twitter. Akun tersebut digunakan untuk mendapatkan API key serta access token yang merupakan kunci untuk mengakses Twitter API. Kedua kunci pengaksesan tersebut dimasukkan pada kode program untuk melakukan pengambilan data dengan menggunakan bahasa pemrograman Python. Selanjutnya digunakan pustaka Tweepy untuk mempermudah pengaksesan Twitter API dalam pengambilan data. Gambar 8 merupakan potongan kode program untuk melakukan crawling data Twitter menggunakan Tweepy.

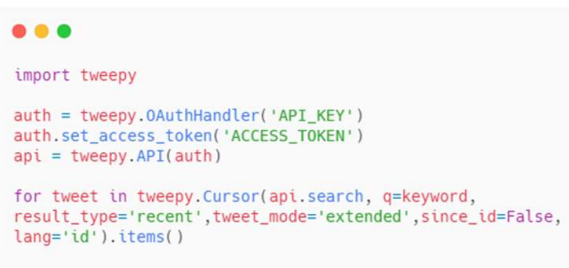

Gambar 8. Kode Program Tweepy
Pada kode program di atas, tweet yang diambil merupakan tweet berbahasa Indonesia yang diatur dengan parameter lang. Pengumpulan data dilakukan antara bulan Juni 2020 sampai November 2020 dan didapatkan 5504 record data. Data yang diambil kemudian disimpan kedalam file berekstensi CSV dengan format penyimpanan seperti pada Tabel 11. Kolom data yang digunakan untuk proses selanjutnya adalah kolom full_text yang berisi konten dari suatu tweet.

Tabel 11. Format Penyimpanan CSV

\begin{tabular}{ll}
\hline Kolom & Deskripsi \\
\hline userid & $\begin{array}{l}\text { ID unik dari pengguna Twitter yang menulis } \\
\text { suatu } \text { tweet. }\end{array}$ \\
\hline user_screen_name & $\begin{array}{l}\text { Username dari akun Twitter pengguna yang } \\
\text { menulis suatu tweet. }\end{array}$ \\
\hline tweet_id & ID unik dari suatu tweet. \\
\hline created_at & Tanggal dan jam dibuatnya tweet. \\
\hline full_text & Isi lengkap dari suatu tweet. \\
\hline keyword & Kata kunci penelusuran tweet \\
\hline scraping_date & Tanggal dan waktu pengambilan tweet. \\
\hline
\end{tabular}

\subsection{Text Preprocessing}

Sebelum proses klasifikasi diimplementasikan, perlu dilakukan preprocessing pada data set. Preprocessing ini bertujuan untuk mengurangi noise pada data set serta mengubah data set menjadi bentuk yang lebih terstuktur. Tahapan yang dilakukan pada preprocessing ini adalah cleansing, case folding, formalisasi, stemming, dan tokenisasi.

\subsection{Labeling}

Proses labeling dilakukan menggunakan aplikasi Sentiment Strength Detection dari hasil penelitian yang dilakukan oleh [13]. Pada aplikasi tersebut dihasilkan tiga kelas sentimen yaitu positif, negatif, dan netral. Data yang telah dilakukan text preprocessing berjumlah 3902 record diberikan label dengan aplikasi tersebut dan didapatkan hasil sebagai berikut.

Tabel 12. Jumlah Data Tiap Kelas pada Data set

\begin{tabular}{ll}
\hline Kelas & Jumlah \\
\hline Positif & 1219 \\
\hline Netral & 1750 \\
\hline Negatif & 933 \\
\hline
\end{tabular}

\subsection{Pembentukan Data Training dan Data Testing}

Setelah preprocessing dan labeling selesai dilakukan maka diperoleh data set siap untuk diproses. Data set terlebih dahulu dibagi menjadi dua yaitu data training dan data testing. Data training merupakan data yang digunakan untuk melatih dan membuat model sedangkan data testing digunakan untuk menguji performa model.

Eksperimen pada penelitian ini dilakukan dengan dua skenario pembagian data. Pertama, dengan proporsi data 90:10 dan skenario kedua dengan proporsi data 80:20.

\subsubsection{Pembagian Data pada Skenario Pertama}

Pada skenario pertama, data training dan data testing dibagi dengan proporsi 90:10. Sebanyak 90\% dari total data set atau 3512 digunakan sebagai data training dan 10\% sisanya atau 390 data digunakan sebagai data testing. Tabel 13 menunjukkan 
jumlah data pada masing-masing kelas yang ada pada data set training.

Dari total 3512 data yang ada pada data training, jumlah data yang memiliki kelas positif adalah 1069 data, jumlah data dengan kelas netral adalah sejumlah 1610 data dan kelas negatif memiliki 833 data.

Tabel 13. Jumlah Data pada Data Training Skenario Pertama

\begin{tabular}{ll}
\hline Kelas & Jumlah \\
\hline Positif & 1069 \\
\hline Netral & 1610 \\
\hline Negatif & 833 \\
\hline
\end{tabular}

Sebanyak $10 \%$ dari data set dijadikan sebagai data testing. Tabel 14 menunjukkan jumlah data pada masing-masing kelas yang ada pada data set testing.

Tabel 14. Jumlah Data pada Data Testing Skenario Pertama

\begin{tabular}{ll}
\hline Kelas & Jumlah \\
\hline Positif & 150 \\
\hline Netral & 140 \\
\hline Negatif & 100 \\
\hline
\end{tabular}

Dari total 390 data yang ada pada data testing, jumlah data yang memiliki kelas positif adalah 150 data, jumlah data dengan kelas netral adalah sejumlah 140 data, dan kelas negatif memiliki 100 data.

\subsubsection{Pembagian Data pada Skenario Kedua}

Pada skenario kedua, data training dan data testing dibagi dengan proporsi $80: 20$. Sebanyak $80 \%$ dari total data set atau 3122 digunakan sebagai data training dan $10 \%$ sisanya atau 780 data digunakan sebagai data testing. Tabel 15 merupakan jumlah data pada masing-masing kelas yang ada pada data data training.

Tabel 15. Jumlah Data pada Data Training Skenario Kedua

\begin{tabular}{ll}
\hline Kelas & Jumlah \\
\hline Positif & 929 \\
\hline Netral & 1460 \\
\hline Negatif & 733 \\
\hline
\end{tabular}

Dari total 3122 data yang ada pada data training, jumlah data yang memiliki kelas positif adalah 929 data, jumlah data dengan kelas netral adalah sejumlah 1460 data dan kelas negatif memiliki 733 data. Sebanyak 10\% dari data set tersebut dijadikan sebagai data testing.

Tabel 16. Jumlah Data pada Data Testing Skenario Kedua

\begin{tabular}{ll}
\hline Kelas & Jumlah \\
\hline Positif & 290 \\
\hline Netral & 290 \\
\hline Negatif & 200 \\
\hline
\end{tabular}

Dari total 780 data yang ada pada data testing, jumlah data yang memiliki kelas positif adalah 290 data, jumlah data dengan kelas netral adalah sejumlah 290 data dan kelas negatif memiliki 200 data.

\subsection{Klasifikasi dengan Deep Neural Network}

Setelah data training dan data testing terbentuk maka selanjutnya dilakukan proses klasifikasi. Untuk dapat menggunakan https://doi.org/10.25077/TEKNOSI.v7i2.2021.108-118 algoritma deep neural network dalam melakukan analisis sentimen maka tahap pertama yang dibutuhkan adalah membuat vocabulary dan membuat sequence dari setiap kalimat yang ada pada data set. Gambar 9 merupakan implementasi kode dari pembentukan vocabulary dan sequence yang digunakan untuk proses klasifikasi DNN.

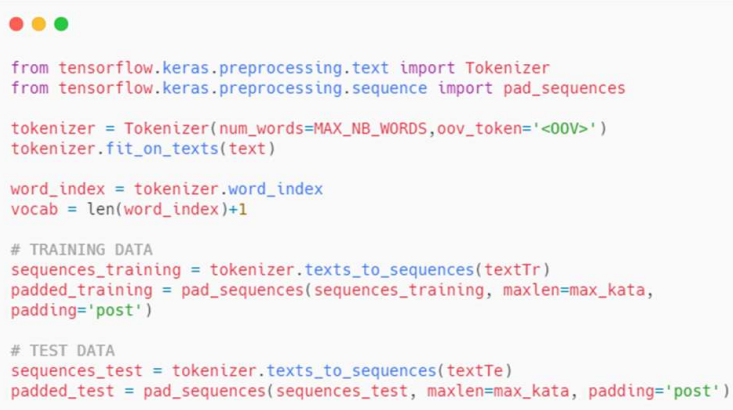

Gambar 9. Implementasi Vocabulary dan Text Sequence

Pembentukan vocabulary dan text sequence dilakukan menggunakan library Tensorflow. Vocabulary merupakan daftar seluruh kata yang ada pada data set yang dibuat dengan memanfaatkan hasil tokenizer. Sequence kemudian dibuat sebanyak dua kali yaitu sequence untuk data set training dan sequence untuk data set testing. Pada sequences tersebut, setiap kalimat diberikan padding post yang bertujuan untuk menyamakan jumlah token kata yang diklasifikasikan dengan algoritma DNN.

Setelah sequences terbentuk maka langkah selanjutnya adalah memuat model FastText pre-trained word embedding. Model word embedding FastText yang berbahasa Indonesia memiliki dimensi vektor sebanyak 300 dimensi untuk setiap token katanya [15]. Berikut merupakan gambar implementasi kode untuk memuat word embedding FastText agar dapat digunakan dengan algoritma DNN.

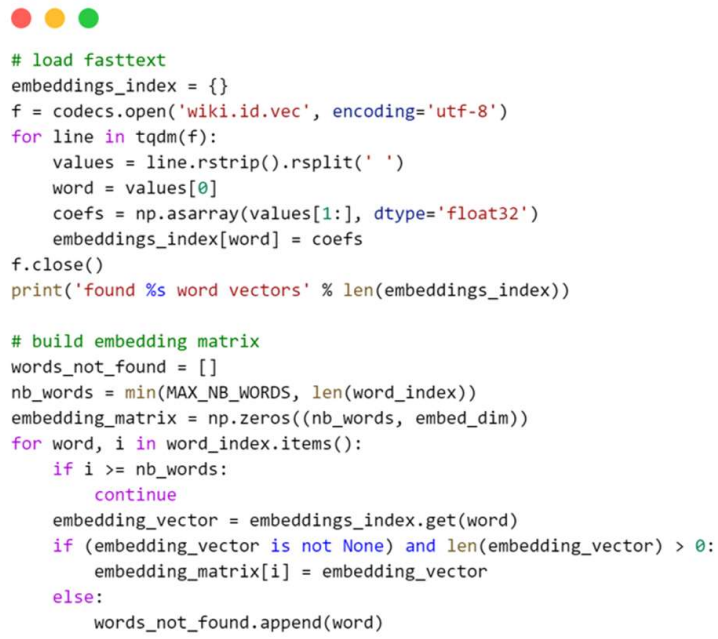

Gambar 10. Implementasi Kode Word Embedding

Hasil keluaran dari kode di atas adalah matriks yang berisi nilai vektor word embedding untuk setiap token kata pada data set. Token kata pada data set yang tidak ditemukan pada vektor word embedding FastText diberi nilai nol sedangkan token kata pada

Erwin Yudi Hidayat 115 
data set yang terindeks pada word embedding FastText diberi nilai vektor sesuai dengan nilai yang ada pada word embedding tersebut. Hasil matriks tersebut kemudian digunakan sebagai layer embedding pada algoritma DNN.

\subsubsection{Tahap Pelatihan dan Pengujian Model}

Tahap pelatihan model dilakukan menggunakan algoritma DNN dengan variasi jumlah hidden layer, susunan node, dan nilai learning rate. Untuk setiap model $\mathrm{DNN}$, layer pertama merupakan layer yang berisi embedding dan layer terakhir merupakan output layer yang berisi tiga node dan menggunakan fungsi aktivasi softmax, di antara layer pertama dan terakhir disisipkan hidden layer dengan jumlah yang bervariasi.

Tabel 17. Hasil Eksperimen Skenario Pertama

\begin{tabular}{|c|c|c|c|c|c|}
\hline $\begin{array}{l}\text { Nama } \\
\text { Model }\end{array}$ & $\begin{array}{l}\text { Hid- } \\
\text { den } \\
\text { La- } \\
\text { yer }\end{array}$ & $\begin{array}{c}\text { Susunan } \\
\text { Node Tiap } \\
\text { Hidden } \\
\text { Layer } \\
\end{array}$ & $\begin{array}{c}\text { Learn } \\
\text {-ing } \\
\text { Rate }\end{array}$ & $\begin{array}{l}\text { Train- } \\
\text { ing } \\
\text { Accu- } \\
\text { racy }\end{array}$ & $\begin{array}{c}\text { Testing } \\
\text { Accu- } \\
\text { racy }\end{array}$ \\
\hline DNN 01 & 1 & Dense(64) & 0.01 & $95.90 \%$ & $85.13 \%$ \\
\hline DNN 02 & 1 & Dense(64) & 0.005 & $94.39 \%$ & $86.67 \%$ \\
\hline DNN_03 & 1 & Dense(128) & 0.01 & $95.73 \%$ & $85.64 \%$ \\
\hline DNN_04 & 1 & Dense(128) & 0.005 & $95.13 \%$ & $86.67 \%$ \\
\hline DNN_05 & 1 & Dense(256) & 0.01 & $95.33 \%$ & $84.87 \%$ \\
\hline DNN 06 & 1 & Dense(256) & 0.005 & $93.05 \%$ & $85.38 \%$ \\
\hline DNN_07 & 2 & $\begin{array}{l}\text { Dense(64) } \\
\text { Dense(128) }\end{array}$ & 0.01 & $95.73 \%$ & $85.13 \%$ \\
\hline DNN_08 & 2 & $\begin{array}{l}\text { Dense (64) } \\
\text { Dense(128) }\end{array}$ & 0.005 & $95.79 \%$ & $86.41 \%$ \\
\hline DNN_09 & 2 & $\begin{array}{l}\text { Dense(256) } \\
\text { Dense(64) }\end{array}$ & 0.01 & $96.10 \%$ & $86.67 \%$ \\
\hline DNN_10 & 2 & $\begin{array}{l}\text { Dense(256) } \\
\text { Dense(64) }\end{array}$ & 0.005 & $94.99 \%$ & $87.69 \%$ \\
\hline DNN_11 & 3 & $\begin{array}{l}\text { Dense(128) } \\
\text { Dense(256) } \\
\text { Dense(128) }\end{array}$ & 0.01 & $96.05 \%$ & $87.95 \%$ \\
\hline DNN_12 & 3 & $\begin{array}{l}\text { Dense(128) } \\
\text { Dense(256) } \\
\text { Dense(128) }\end{array}$ & 0.005 & $95.30 \%$ & $88.72 \%$ \\
\hline DNN_13 & 3 & $\begin{array}{l}\text { Dense(256) } \\
\text { Dense(128) } \\
\text { Dense(128) }\end{array}$ & 0.005 & $96.75 \%$ & $87.18 \%$ \\
\hline DNN_14 & 3 & $\begin{array}{l}\text { Dense(128) } \\
\text { Dense(128) } \\
\text { Dense(128) }\end{array}$ & 0.005 & $95.96 \%$ & $87.18 \%$ \\
\hline DNN_15 & 4 & $\begin{array}{l}\text { Dense(64) } \\
\text { Dense(128) } \\
\text { Dense(256) } \\
\text { Dense(128) } \\
\end{array}$ & 0.005 & $95.44 \%$ & $84.62 \%$ \\
\hline DNN_16 & 4 & $\begin{array}{l}\text { Dense }(64) \\
\text { Dense(128) } \\
\text { Dense }(256) \\
\text { Dense }(128) \\
\end{array}$ & 0.0005 & $95.30 \%$ & $85.13 \%$ \\
\hline DNN_17 & 4 & $\begin{array}{l}\text { Dense }(256) \\
\text { Dense }(128) \\
\text { Dense }(128) \\
\text { Dense }(256) \\
\end{array}$ & 0.005 & $94.22 \%$ & $86.15 \%$ \\
\hline DNN_18 & 5 & $\begin{array}{l}\text { Dense }(128) \\
\text { Dense }(128) \\
\text { Dense }(128) \\
\text { Dense }(256) \\
\text { Dense }(256) \\
\end{array}$ & 0.005 & $95.96 \%$ & $86.41 \%$ \\
\hline DNN_19 & 5 & $\begin{array}{l}\text { Dense }(128) \\
\text { Dense }(128) \\
\text { Dense }(128) \\
\text { Dense }(256) \\
\text { Dense }(256)\end{array}$ & 0.0005 & $95.10 \%$ & $88.21 \%$ \\
\hline DNN_20 & 5 & $\begin{array}{l}\text { Dense }(256) \\
\text { Dense }(128) \\
\text { Dense }(128) \\
\text { Dense }(256) \\
\text { Dense }(256)\end{array}$ & 0.005 & $95.67 \%$ & $87.44 \%$ \\
\hline
\end{tabular}

116 Erwin Yudi Hidayat
Eksperimen dilakukan dengan dua skenario yaitu skenario pertama dengan proporsi data set 90:10. Sebanyak 3512 data training dan 390 data testing digunakan pada proses pelatihan dan pengujian. Tabel 17 menunjukkan hasil eksperimen pelatihan dan pengujian model DNN untuk skenario pertama. Adapun hasil eksperimen dari skenario kedua dengan proporsi data training sebanyak 3112 dan 780 data testing, disajikan dalam Tabel 18.

Tabel 18. Hasil Eksperimen Skenario Kedua

\begin{tabular}{|c|c|c|c|c|c|}
\hline $\begin{array}{l}\text { Nama } \\
\text { Model }\end{array}$ & $\begin{array}{l}\text { Hid- } \\
\text { den } \\
\text { La- } \\
\text { yer }\end{array}$ & $\begin{array}{c}\text { Susunan } \\
\text { Node Tiap } \\
\text { Hidden } \\
\text { Layer }\end{array}$ & $\begin{array}{c}\text { Learn } \\
\text {-ing } \\
\text { Rate }\end{array}$ & $\begin{array}{l}\text { Train- } \\
\text { ing } \\
\text { Accu- } \\
\text { racy }\end{array}$ & $\begin{array}{c}\text { Testing } \\
\text { Accu- } \\
\text { racy }\end{array}$ \\
\hline DNN 21 & 1 & Dense(64) & 0.01 & $91.38 \%$ & $82.95 \%$ \\
\hline DNN 22 & 1 & Dense(64) & 0.005 & $91.38 \%$ & $83.46 \%$ \\
\hline DNN 23 & 1 & Dense(128) & 0.01 & $90.20 \%$ & $82.18 \%$ \\
\hline DNN 24 & 1 & Dense(128) & 0.005 & $89.78 \%$ & $83.21 \%$ \\
\hline DNN_25 & 2 & $\begin{array}{l}\text { Dense(64) } \\
\text { Dense(128) }\end{array}$ & 0.01 & $91.80 \%$ & $76.67 \%$ \\
\hline DNN_26 & 2 & $\begin{array}{l}\text { Dense }(64) \\
\text { Dense(128) }\end{array}$ & 0.005 & $89.97 \%$ & $81.97 \%$ \\
\hline DNN_27 & 2 & $\begin{array}{l}\text { Dense(128) } \\
\text { Dense(128) }\end{array}$ & 0.01 & $90.26 \%$ & $81.41 \%$ \\
\hline DNN_28 & 2 & $\begin{array}{l}\text { Dense(128) } \\
\text { Dense(256) }\end{array}$ & 0.01 & $91.13 \%$ & $80.00 \%$ \\
\hline DNN_29 & 3 & $\begin{array}{l}\text { Dense(128) } \\
\text { Dense(256) } \\
\text { Dense(128) }\end{array}$ & 0.01 & $93.24 \%$ & $82.18 \%$ \\
\hline DNN_30 & 3 & $\begin{array}{l}\text { Dense(128) } \\
\text { Dense(256) } \\
\text { Dense(128) }\end{array}$ & 0.005 & $91.93 \%$ & $82.56 \%$ \\
\hline DNN_31 & 3 & $\begin{array}{l}\text { Dense(128) } \\
\text { Dense(256) } \\
\text { Dense(256) }\end{array}$ & 0.01 & $91.06 \%$ & $83.59 \%$ \\
\hline DNN_32 & 3 & $\begin{array}{l}\text { Dense(64) } \\
\text { Dense(128) } \\
\text { Dense(256) }\end{array}$ & 0.01 & $91.32 \%$ & $82.95 \%$ \\
\hline DNN_33 & 4 & $\begin{array}{l}\text { Dense(64) } \\
\text { Dense(128) } \\
\text { Dense(256) } \\
\text { Dense(128) } \\
\end{array}$ & 0.01 & $92.70 \%$ & $83.08 \%$ \\
\hline DNN_34 & 4 & $\begin{array}{l}\text { Dense(64) } \\
\text { Dense(128) } \\
\text { Dense(256) } \\
\text { Dense(128) } \\
\end{array}$ & 0.005 & $90.71 \%$ & $83.33 \%$ \\
\hline DNN_35 & 4 & $\begin{array}{l}\text { Dense(128) } \\
\text { Dense(128) } \\
\text { Dense(128) } \\
\text { Dense(256) }\end{array}$ & 0.01 & $90.58 \%$ & $80.90 \%$ \\
\hline DNN_36 & 4 & $\begin{array}{l}\text { Dense(256) } \\
\text { Dense(128) } \\
\text { Dense(128) } \\
\text { Dense(128) }\end{array}$ & 0.01 & $90.97 \%$ & $79.36 \%$ \\
\hline DNN_37 & 5 & $\begin{array}{l}\text { Dense(128) } \\
\text { Dense(128) } \\
\text { Dense(128) } \\
\text { Dense(256) } \\
\text { Dense(256) }\end{array}$ & 0.01 & $91.61 \%$ & $76.67 \%$ \\
\hline DNN_38 & 5 & $\begin{array}{l}\text { Dense(128) } \\
\text { Dense(128) } \\
\text { Dense(128) } \\
\text { Dense(256) } \\
\text { Dense(256) }\end{array}$ & 0.005 & $90.65 \%$ & $82.56 \%$ \\
\hline DNN_39 & 5 & $\begin{array}{l}\text { Dense(256) } \\
\text { Dense(256) } \\
\text { Dense(128) } \\
\text { Dense(128) } \\
\text { Dense(128) }\end{array}$ & 0.01 & $89.30 \%$ & $78.97 \%$ \\
\hline DNN_40 & 5 & $\begin{array}{l}\text { Dense(256) } \\
\text { Dense(256) } \\
\text { Dense(128) } \\
\text { Dense(128) } \\
\text { Dense(64) }\end{array}$ & 0.01 & $90.49 \%$ & $81.15 \%$ \\
\hline
\end{tabular}




\section{PEMBAHASAN}

\subsection{Analisis Eksperimen Skenario Pertama}

Eksperimen pertama dengan 80:20 perbandingan data training dan testing dilakukan dengan menggunakan 20 model yang bervariasi parameternya. Hasilnya, pada Gambar 11 dapat ditunjukkan bahwa model DNN_12 memperoleh akurasi tertinggi dengan persentase $88.72 \%$. Hasil tersebut diperoleh dari model yang tersusun oleh 3 hidden layer dengan jumlah masing-masing node-nya berturut-turut adalah 128,256 , dan 128 , serta menggunakan learning rate bernilai 0.005 .

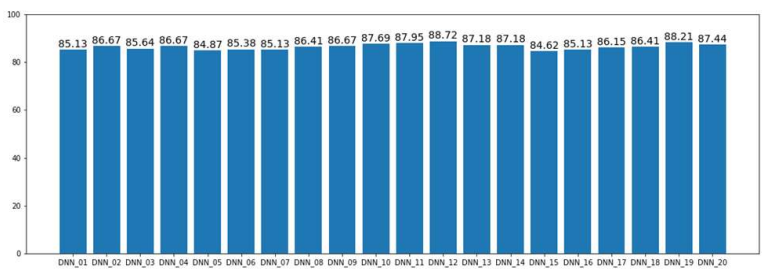

Gambar 11. Akurasi Setiap Model Skenario Pertama

Pada Tabel 17 dapat diperhatikan bahwa semakin banyak jumlah hidden layer maka nilai akurasi yang didapatkan tidak selalu lebih baik. Contohnya pada model DNN_03 dan DNN_04 yang keduanya memiliki 1 hidden layer dan menghasilkan nilai akurasi yang lebih baik dari model DNN_15 dan DNN_16 yang memiliki 4 hidden layer.

Selain itu, dari 20 model yang ada pada Tabel 17 juga ditunjukkan bahwa nilai learning rate berpengaruh terhadap akurasi model. Pada model dengan jumlah hidden layer dan susunan node yang sama maka nilai learning rate yang lebih kecil memiliki nilai akurasi yang lebih besar dari model lainnya. Contohnya pada model DNN_18 dan DNN_19. Kedua model tersebut sama-sama memiliki 5 hidden layer dengan susunan node 128, 128, 128, 256, dan 256 node. Model DNN_18 dengan nilai learning rate sebesar 0.005 menghasilkan akurasi sebesar $86.41 \%$ sedangkan model DNN_19 yang memiliki learning rate sebesar 0.0005 menghasilkan akurasi sebesar $88.21 \%$.

Kemudian hasil akurasi pada model yang memiliki parameter jumlah hidden layer, dan learning rate yang sama namun dengan jumlah node yang berbeda maka semakin banyak jumlah node tidak menjamin semakin besarnya akurasi yang dihasilkan. Contohnya seperti pada model DNN_01, DNN_03,DNN_5 yang ketiganya memiliki 1 hidden layer dan learning rate 0.01 dengan jumlah node untuk setiap model berturut-turut sebanyak 64, 128, dan 256 node. Akurasi yang dihasilkan dari model tersebut bervariasi dan tidak bergantung pada besarnya jumlah node pada layer tersebut.

\subsection{Analisis Eksperimen Skenario Kedua}

Sebanyak 3112 data training dan 780 data testing digunakan pada proses pelatihan dan pengujian ini.

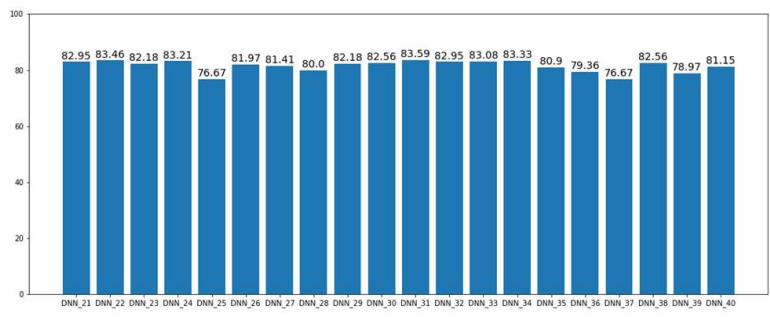

Gambar 12. Akurasi Setiap Model Skenario Kedua

Dari eksperimen pada Tabel 18 maka dapat ditunjukkan bahwa semakin banyak jumlah layer maka tidak menjamin model mendapatkan akurasi yang lebih besar. Contohnya pada model DNN_21 dengan 1 hidden layer memiliki akurasi yang lebih tinggi yaitu $82.95 \%$ dari model DNN_26 dengan 2 hidden layer yang memiliki akurasi $81.97 \%$.

Di sisi lain, untuk model dengan susunan node yang sama maka learning rate yang lebih kecil memiliki nilai akurasi yang lebih baik. Contohnya pada model DNN_29 dan DNN_30 yang masing-masing memiliki susunan node yang sama. Model DNN_29 yang mempunyai learning rate 0.01 memperoleh akurasi yang lebih kecil yaitu $82.18 \%$ dari model DNN_30 dengan learning rate 0.005 yang memiliki akurasi $82.56 \%$.

Dari grafik hasil 20 model pelatihan skenario kedua pada Gambar 12, maka dapat disimpulkan bahwa model terbaik ada pada model DNN_31 yang memiliki 3 hidden layer dengan susunan node 128, 256, 256 node. Learning rate yang digunakan pada model DNN_31 adalah 0.01 dan menghasilkan hasil akurasi sebesar $83.59 \%$. Namun, performa model terbaik pada skenario kedua mendapatkan akurasi yang lebih kecil dari performa model terbaik pada skenario pertama yang ditunjukkan pada Tabel 17 yaitu model DNN_12 dengan nilai akurasi sebesar $88.72 \%$.

Angka tersebut menunjukkan akurasi yang lebih baik jika dibandingkan dengan performa metode SVM (RBF) dan K-NN pada [7], dengan akurasi tertinggi $87 \%$ dan $82 \%$ berturut-turut. Hasil ini dapat dijadikan sebagai referensi untuk penelitian selanjutnya pada bidang analisis sentimen, atau penelitian sejenis.

\section{KESIMPULAN}

Analisis sentimen Twitter untuk menilai opini terhadap perusahaan publik menggunakan algoritma DNN berhasil diterapkan. Tahap awal penelitian dilakukan dengan pengumpulan data tweet yang diambil dengan Twitter API, pada rentang Juni 2020 sampai November 2020 dan didapatkan 5504 record data. Data tersebut kemudian dilakukan preprocessing berupa cleansing, case folding, formalisasi, stemming, dan tokenisasi. Selanjutnya pelabelan diselesaikan menggunakan Sentiment Strength Detection, sehingga siap untuk dimodelkan dan diuji.

Algoritma DNN untuk klasifikasi tweet berbahasa Indonesia ini dilakukan secara otomatis berdasarkan tiga kelas yaitu positif, negatif, dan netral. Klasifikasi diterapkan menggunakan pretrained word embedding FastText yang memiliki dimensi embedding sejumlah 300 dimensi. 
Eksperimen dilakukan dengan dua skenario proporsi data training dan testing, pertama 90:10 dan kedua adalah 80:20. Eksperimen skenario pertama dengan total 3902 menghasilkan model DNN dengan performa terbaik dari seluruh eksperimen. Model tersebut tersusun dari 3 hidden layer dengan susunan node tiap layer pada model tersebut yaitu 128, 256, 128 node dan menggunakan learning rate sebesar 0.005 . Nilai akurasi yang diperoleh dari model DNN tersebut adalah $88.72 \%$.

\section{DAFTAR PUSTAKA}

[1] C. Eforis, "Pengaruh Kepemilikan Negara Dan Kepemilikan Publik Terhadap Kinerja Keuangan Bumn (Studi Pada Perusahaan Bumn Yang Go Public Pada Tahun 2012 - 2015)," Ultim. J. Ilmu Akunt., vol. 9, no. 1, pp. 18-31, 2017.

[2] B. Nugraha, "Metode Klasifikasi Analisis Sentimen pada Media Sosial," Syntax J. Inform., vol. 9, no. 2, pp. 109-118, 2020.

[3] Z. Jianqiang, G. Xiaolin, and Z. Xuejun, "Deep Convolution Neural Networks for Twitter Sentiment Analysis," IEEE Access, vol. 6, pp. 23253-23260, 2018.

[4] A. Rossi, T. Lestari, R. Setya Perdana, and M. A. Fauzi, “Analisis Sentimen Tentang Opini Pilkada DKI 2017 Pada Dokumen Twitter Berbahasa Indonesia Menggunakan Näive Bayes dan Pembobotan Emoji," $J$. Pengemb. Teknol. Inf. dan Ilmu Komput., vol. 1, no. 12, pp. 1718-1724, 2017.

[5] A. M. Pravina, I. Cholissodin, and P. P. Adikara, "Analisis Sentimen Tentang Opini Maskapai Penerbangan pada Dokumen Twitter Menggunakan Algoritme Support Vector Machine (SVM)," J. Pengemb. Teknol. Inf. dan Ilmu Komput., vol. 3, no. 3, pp. 2789-2797, 2019.

[6] U. Rofiqoh, R. S. Perdana, and M. A. Fauzi, "Analisis Sentimen Tingkat Kepuasan Pengguna Penyedia Layanan Telekomunikasi Seluler Indonesia Pada Twitter Dengan Metode Support Vector Machine dan Lexion Based Feature," J. Pengemb. Teknol. Inf. dan Ilmu Komput. Univ. Brawijaya, vol. 1, no. 12, pp. 17251732, 2017.

[7] R. Saputri, W. Winahju, and K Fithriasari, "Klasifikasi Sentimen Wisatawan Candi Borobudur pada Situs TripAdvisor Menggunakan Support Vector Machine dan K-Nearest Neighbor," J. Sains dan Seni ITS, vol. 8, no. 2, pp. 349-356, 2019.

[8] R. Cahyani and P. P. Adikara, "Analisis Sentimen terhadap Ulasan Hotel menggunakan Boosting Weighted Extreme Learning Machine," vol. 3, no. 8, pp. 7767-7773, 2019.

[9] W. Parasati, F. A. Bachtiar, and N. Y. Setiawan, "Analisis Sentimen Berbasis Aspek pada Ulasan Pelanggan Restoran Bakso President Malang dengan Metode Naïve Bayes Classifier," J. Pengemb. Teknol. Inf. dan Ilmu Komput., vol. 4, no. 4, pp. 1090-1099, 2020.

[10] M. A. Azim and M. H. Bhuiyan, "Text to emotion extraction using supervised machine learning techniques," Telkomnika (Telecommunication Comput. Electron. Control., vol. 16, no. 3, pp. 1394-1401, 2018.

[11] K. T. Chitty-Venkata and A. K. Somani, "Array aware training/pruning: Methods for efficient forward propagation on array-based neural network accelerators," Proc. Int. Conf. Appl. Syst. Archit. Process., vol. 2020-July, pp. 37-44, 2020.

[12] W. C. F. Mariel, S. Mariyah, and S. Pramana, "Sentiment analysis: A comparison of deep learning neural network algorithm with SVM and naïve Bayes for
Indonesian text," J. Phys. Conf. Ser., vol. 971, no. 1, 2018.

[13] D. H. Wahid and A. SN, "Peringkasan Sentimen Esktraktif di Twitter Menggunakan Hybrid TF-IDF dan Cosine Similarity," IJCCS (Indonesian J. Comput. Cybern. Syst., vol. 10, no. 2, p. 207, 2016.

[14] L. Zhang, S. Wang, and B. Liu, "Deep learning for sentiment analysis: A survey," Wiley Interdiscip. Rev. Data Min. Knowl. Discov., vol. 8, no. 4, pp. 1-25, 2018. [15] Facebook, "Wiki word vectors - fastText," 2017. .

\section{NOMENKLATUR}

$\begin{array}{ll}\mathrm{y} & \text { output } \\ \alpha & \text { fungsi aktivasi } \\ \mathrm{w} & \text { bobot } \\ \mathrm{x} & \text { input } \\ \mathrm{b} & \text { bias } \\ \mathrm{e} & \text { bilangan alami } \\ \text { max } & \text { nilai maksimum } \\ \mathrm{j} & \text { neuron ke-j pada layer } \\ \mathrm{K} & \text { jumlah kelas }\end{array}$

\section{BIODATA PENULIS}

\section{Erwin Yudi Hidayat}

Menamatkan pendidikan sarjana di Program Studi Teknik Informatika, Fakultas Ilmu Komputer, Universitas Dian Nuswantoro, sebagai Sarjana Komputer (S.Kom). Studi jenjang S2 diselesaikan di Universiti Teknikal Malaysia Melaka (UTeM), dengan konsentrasi pada bidang kecerdasan buatan. Penulis tertarik dalam penelitian machine learning, deep learning, dan pengolahan citra digital. Saat ini menjadi staf pengajar pada almamater di tempat kuliah S1 dulu ditempuh.

\section{Raindy Wicaksana Hardiansyah}

Penulis adalah alumni Program Studi Teknik Informatika, Fakultas Ilmu Komputer, Universitas Dian Nuswantoro, Semarang. Ketertarikan akan text mining dan kecerdasan buatan, mengantarkan penulis terhadap penelitian analisis sentimen. Gelar S.Kom yang diperoleh diselesaikan dalam waktu 3,5 tahun dan lulus dengan cumlaude.

\section{Affandy}

Penulis adalah staf pengajar aktif di Fakultas Ilmu Komputer, Universitas Dian Nuswantoro, Semarang, tempat program sarjana dan magister diselesaikan. Gelar Doctor of Philosophy diperoleh dari Universiti Teknikal Malaysia Melaka (UTeM), dengan minat penelitian pada software visualization, software engineering, dan Computer Science Education 